\title{
Peran pola asuh orangtua dan penggunaan gadget terhadap interaksi sosial anak prasekolah
}

\author{
Kadek Dwinita Viandari dan Kadek Pande Ary Susilawati \\ Program Studi Sarjana Psikologi, Fakultas Kedokteran, Universitas Udayana \\ pandeary@unud.ac.id
}

\begin{abstract}
Abstrak
Masa prasekolah adalah masa anak-anak belajar mengenal lingkungan sosial, mengembangkan potensi yang dimiliki, dan membentuk kemandirian. Kemampuan berinteraksi sosial yang baik sangat diperlukan pada masa ini, guna mencapai perkembangan sosial yang optimal. Pola asuh yang diterapkan oleh orangtua terhadap anak dapat mempengaruhi kemampuan interaksi sosial anak. Belajar dari figur orangtua, anak-anak dapat menerapkan cara berinteraksi dan melakukan hubungan timbal balik dengan teman seusianya. Penggunaan teknologi gadget pada anak prasekolah juga dapat memberikan dampak positif maupun negatif terhadap interaksi sosial anak di sekolah. Penelitian ini bertujuan untuk mengetahui peran pola asuh orangtua dan penggunaan gadget terhadap interaksi sosial anak prasekolah. Subjek dalam penelitian ini berjumlah 100 anak prasekolah di Taman Kanak-Kanak Adhi Mekar dan Taman Kanak-Kanak Bintang Besar yang dipilih dengan menggunakan teknik simple random sampling. Instrumen dalam penelitian ini adalah skala interaksi sosial, skala pola asuh orangtua, dan angket penggunaan gadget. Hipotesis penelitian diuji menggunakan teknik analysis of covariance (ancova). Hasil analisis menunjukkan nilai signifikansi pada corrected model sebesar $0,000(\mathrm{p}<0,05)$, sehingga dapat disimpulkan bahwa pola asuh orangtua dan penggunaan gadget secara bersama-sama berperan terhadap interaksi sosial anak prasekolah.
\end{abstract}

Kata kunci: Interaksi sosial, pola asuh orangtua, penggunaan gadget.

\begin{abstract}
Preschool is time for children to learn about the social environment, develop their potential, and form self-reliance. Good social interaction skills are needed at this time, in order to achieve optimal social development. Parenting styles applied by parents to children affected the social interaction abilities. Learning from parent figures, children can apply ways of interacting and reciprocal relationships with their peers. The use of gadget technology in preschoolers have a positive and negative impact on the social interactions of the children at school. The purpose of this study was to determine the role of parenting styles and the use of gadgets toward social interactions of preschoolers. Subjects in this study were 100 preschoolers in Adhi Mekar Kindergarten and Kindergarten Star Big selected by using simple random sampling technique. Instruments in this study were the scale of social interaction, parenting styles, and questionnaire use of gadgets. The results were tested using the technique of analysis of covariance (ancova). The results of the analysis show the significance value of the corrected model of $0.000(p<0.05)$. Based on the study, it concluded that parenting styles and the use of gadgets together contribute to the social interaction of preschool children.
\end{abstract}

Keywords: Social interaction, parenting styles, use of gadgets. 


\section{LATAR BELAKANG}

Masa kanak-kanak awal adalah periode perkembangan yang dimulai dari akhir masa bayi hingga usia 6 tahun. Periode ini disebut sebagai masa prasekolah, pada masa ini anak belajar untuk lebih mandiri dan merawat dirinya sendiri, mengembangkan sejumlah keterampilan kesiapan sekolah (mengikuti instruksi, mengenali huruf) dan meluangkan banyak waktu untuk bermain dengan kawan-kawan sebaya (Santrock, 2007). Perkembangan otak pada anak usia dini (0-6 tahun) mengalami percepatan hingga $80 \%$ dari keseluruhan otak orang dewasa. Hal ini menunjukkan bahwa seluruh potensi dan kecerdasan serta dasar-dasar perilaku seseorang telah mulai terbentuk pada usia ini. Periode ini disebut sebagai periode emas, atau yang lebih dikenal sebagai the golden ages (Suyadi, 2010).

Pendidikan di masa prasekolah sangatlah penting diberikan sesuai dengan standar pendidikan yang tepat, untuk mempersiapkan anak-anak menghadapi masa perkembangan selanjutnya yang akan dihadapkan pada dunia yang lebih luas beserta kebudayaannya. Taman Kanak-kanak (TK) merupakan salah satu alternatif pendidikan formal untuk anak usia prasekolah yang bertujuan untuk membantu meletakkan dasar ke arah perkembangan sikap, intelektual, keterampilan fisik dan motorik, sosial, moral, dan daya cipta yang diperlukan oleh anak-anak untuk menyesuaikan diri dengan lingkungannya, serta untuk pertumbuhan dan perkembangan pada tahap selanjutnya. TK merupakan area penting sebagai tempat anak-anak belajar mengembangkan potensi yang dimiliki dan mengembangkan kemandirian. Selain itu, di TK anak juga memperoleh pengalaman lain yaitu tunduk pada otoritas selain orangtua. Anak-anak mendapat bimbingan dari pendidik dengan gaya dan pendekatan yang berbeda yang selama ini diperoleh dari orangtuanya. Pengalaman inilah yang membuat anak menjadi lebih memahami perlunya melihat persoalan dari sudut pandang orang lain. Kemampuan inilah, yang secara akademik disebut sebagai kemampuan kognisi sosial yang pada tahap perkembangan selanjutnya akan menjadi pondasi bagi anak untuk dapat bersosialisasi dengan baik (Izzaty, 2017).

Interaksi sosial merupakan hubungan-hubungan sosial yang menyangkut hubungan antar individu, individu dengan kelompok, dan kelompok dengan kelompok. Interaksi sosial akan terjadi jika adanya sebuah kontak sosial dan adanya komunikasi. Interaksi sosial merupakan kunci dari semua kehidupan sosial, oleh karena itu tanpa interaksi sosial, tak akan mungkin ada kehidupan bersama (Soekanto, 1992). Pada anak usia dini interaksi sosial memanglah sangat dibutuhkan karena anak nantinya akan diajarkan bagaimana hidup bermasyarakat, lalu anak juga akan diajarkan berbagai peran yang nantinya akan menjadi indentifikasi dirinya, selain itu pula saat melakukan interasi sosial anak akan memperoleh berbagai informasi yang ada disekitarnya. Anak-anak mulai beradaptasi dengan teman sebaya dan lingkungannya untuk mencapai perkembangan sosial yang optimal.

Idealnya, anak usia dini yang berada pada masa prasekolah memerlukan kemampuan interaksi sosial yang baik agar dapat menyesuaikan diri dan mengembangkan diri secara optimal.
Pada kenyataannya, tidak semua anak mampu berinteraksi sosial dengan baik, karena setiap anak memiliki kesiapan fisik dan mental yang beragam untuk menyesuaikan diri dengan lingkungannya, sehingga ada kalanya anak-anak memiliki hambatan selama proses pengembangan diri pada masa prasekolah. Salah satu faktor yang memengaruhi interaksi sosial anak adalah pola asuh orangtua. Perkembangan sosial anak sangat dipengaruhi oleh proses perlakuan atau bimbingan orangtua terhadap anak dalam berbagai aspek kehidupan sosial, atau norma-norma kehidupan bermasyarakat serta mendorong dan memberikan contoh kepada anak bagaimana menerapkan norma-norma ini dalam kehidupan sehari-hari (Susanto, 2012).

Berdasarkan hasil studi pendahuluan menyatakan bahwa terdapat berbagai gaya pengasuhan yang diberikan oleh orangtua terhadap anak, khususnya dalam memberikan pendampingan penggunaan gadget dalam kehidupan seharihari. Salah seorang wali murid membatasi anak dalam penggunaan gadget, sehingga tidak ada perubahan perilaku negatif yang ditunjukkan oleh anak dalam kehidupan seharihari. Hal yang sama juga dilakukan oleh seorang wali murid, orangtua membatasi waktu penggunaan gadget kepada anak, dengan kata lain memperbolehkan anak bermain dengan gadget hanya ketika hari libur saja dan tidak memberikannya saat hari sekolah, sehingga orangtua tidak merasakan adanya perubahan pada anak selama mengenal gadget. Wali murid lainnya juga memberikan pendampingan terhadap anak dalam menggunakan gadget, hal tersebut dilakukan agar anak tidak memiliki pandangan yang keliru terhadap informasi yang diterima dari gadget itu sendiri, sehingga anak dapat tumbuh menjadi pribadi yang high technology dan cepat menyerap informasi. Selain itu, terdapat gaya pengasuhan berbeda dari salah seorang wali murid, dimana orangtua memberikan kebebasan waktu penggunaan gadget pada anak, hal tersebut menyebabkan konsenterasi belajar anak menurun karena lebih memilih bermain gadget dibandingkan belajar. Wali murid lainnya yang memberikan gaya pengasuhan yang sama juga menyatakan bahwa anak menjadi sangat ketergantungan pada gadget dan sering meminta untuk bermain game atau youtube, sehingga anak menjadi pribadi yang kurang mampu bersosialisasi di lingkungan sekitarnya, serta kurang tanggap terhadap himbauan orangtua atau pun keluarga.

Pengasuhan yang tepat dari orangtua sangatlah penting diberikan kepada anak, karena anak masih terlalu muda dan belum memiliki pengalaman untuk membimbing perkembangannya sendiri ke arah kematangan. Arahan serta bimbingan orangtua menjadi kunci keberhasilan anak untuk dapat membentuk kepribadian yang mandiri dan kompeten secara sosial.

Pola asuh merupakan sikap orangtua dalam berinteraksi, membimbing, membina, dan mendidik anak-anaknya dalam kehidupan sehari-hari dengan harapan menjadikan anak sukses menjalani kehidupan ini. Hal ini sejalan dengan pendapat Euis (2004) yang menyatakan bahwa pola asuh merupakan serangkaian interaksi yang intensif, orangtua mengarahkan anak untuk memiliki kecakapan hidup. Menurut Baumrind (dalam Mussen, 1994) terdapat tiga gaya pengasuhan yang 
diterapkan orangtua terhadap anak, diantaranya adalah pola asuh otoriter, pola asuh permisif, dan pola asuh demokratis.

Pola asuh otoriter menggunakan pendekatan yang memaksakan kehendak, suatu peraturan yang dicanangkan orangtua dan harus dituruti oleh anak. Pola asuh permisif mengggunakan pendekatan yang serba membolehkan dan mengijinkan. Pola asuh demokratis menggunakan pendekatan rasional dan demokratis, rang tua sangat memperhatikan dan memenuhi kebutuhan anak dengan pertimbangan faktor kepentingan dan kebutuhan yang realistis.

Bentuk pola asuh yang diberikan orangtua kepada anak akan memengaruhi perkembangan sosial anak. Berdasarkan penelitian yang dilakukan oleh Suharsono (2009) menemukan bahwa terdapat hubungan positif antara pola asuh orangtua dengan kemampuan sosialisasi anak usia dini. Hal ini sejalan dengan pandangan sejumlah teoretisi dan peneliti (dalam Santrock, 2007) yang mengatakan bahwa hubungan orangtua dengan anak berfungsi sebagai landasan emosional yang digunakan anak untuk mengeksplorasi dan menikmati hubungan dengan teman sebaya. Hubungan orangtua dengan anak memengaruhi hubungan anak dengan teman sebaya. Anak-anak belajar tentang bagaimana berhubungan dengan figur pemegang otoritas dari orangtuanya. Melalui teman sebaya, anak-anak juga belajar mengenai cara berinteraksi dan melakukan hubungan timbal balik dengan teman seusianya (Santrock, 2007).

Faktor penting lain yang menghambat perkembangan sosial anak prasekolah adalah gadget. Gempuran teknologi yang semakin canggih memengaruhi pola interaksi sosial anak terhadap lingkungan sekitarnya. Pernyataan ini sesuai dengan hasil studi pendahuluan di TK N Pembina Denpasar, dimana terdapat 11 responden $(61,1 \%)$ yang menyatakan bahwa gadget memberi pengaruh terhadap kehidupan sosial anak, mulai dari rendahnya kemampuan bersosialisasi dan beradaptasi di lingkungan sosial, kecenderungan untuk bermain dan menghabiskan waktu dengan gadget, sehingga kurangnya minat siswa untuk belajar, menjadi pemalas, kurang responsif dan interaktif terhadap lingkungan di sekitarnya, hingga meniru gaya bicara maupun perilaku pada karakter film cartoon. Sedangkan 7 responden lainnya $(38,9 \%)$ mengungkapkan bahwa melalui gadget, anak menjadi lebih pintar, lebih mengetahui berbagai informasi mengenai pelajaran sekolah, film anak-anak, dan teknologi.

Berbeda dengan TK N Pembina Denpasar, hasil kuesioner di TK Adhi Mekar Indonesia (AMI) menunjukkan 10 responden $(55,5 \%)$ menyatakan bahwa gadget memberi pengaruh terhadap kehidupan sosial anak, mulai dari anak lebih suka bermain dan menghabiskan waktu dengan gadget, sehingga kurangnya minat siswa untuk belajar, anak menjadi lebih emosional, sedikit mengalami keterlambatan berbicara, kurang mampu bersosialisasi, serta kurang responsif terhadap orangtua maupun keluarganya. 6 responden lainnya $(33,3 \%)$ mengemukakan bahwa gadget mampu menjadikan anak lebih high technologi, cepat menyerap informasi, lebih awal mengenal angka, warna, permainan seusianya, bahasa inggris, dan menjadi pintar bernyanyi. Selain itu, 2 responden lainnya
$(11,1 \%)$ mengungkapkan bahwa gadget memberikan pengaruh yang seimbang.

Anak mampu menerima informasi dan menyerap ilmu pengetahuan dari berbagai media, salah satunya melalui teknologi gadget. Gadget adalah sebuah istilah yang berasal dari Bahasa Inggris yang merujuk pada perangkat elektronik kecil yang memiliki fungsi khusus untuk mengunduh informasi-informasi terbaru dengan berbagai teknologi maupun fitur terbaru, sehingga membuat hidup manusia menjadi lebih praktis (Indrawan, 2014). Gadget yang memiliki akses yang tidak terbatas dapat memberikan sumbangan positif terhadap wawasan dan pengetahuan anak, baik yang bersifat akademik maupun non akademik.

Berdasarkan hasil penelitian yang dilakukan oleh Marsal dan Hidayati (2017), menunjukkan bahwa penggunaan smartphone berpengaruh signifikan terhadap pola interaksi sosial anak balita sebesar 40,2\%. Penggunaan smartphone selain untuk bermain, bisa bermanfaat untuk belajar. Hal ini dikarenakan smartphone salah satu bentuk teknologi canggih saat ini dan sudah menjadi kebutuhan bagi setiap orang. Penggunaan smartphone menjadi magnet yang kuat dalam ingatan anak balita, sehingga penggunaan smartphone cenderung membuat anak balita bersifat individual dan kurang peka terhadap lingkungan. Orangtua harus mempertimbangkan berapa banyak waktu yang diperbolehkan untuk anak usia prasekolah dalam bermain gadget, karena total lama penggunaan gadget dapat memengaruhi perkembangan anak (Starburger, 2011). Waktu ideal lama anak usia prasekolah dalam menggunakan gadget yaitu 30 menit hingga 1 jam dalam sehari (Sigman, 2010).

Berdasarkan uraian di atas, penelitian ini dilakukan untuk mengetahui apakah pola asuh orangtua dan penggunaan gadget berperan terhadap interaksi sosial anak prasekolah.

\section{METODE PENELITIAN}

\section{Variabel dan Definisi Operasional}

Variabel tergantung dalam penelitian ini adalah interaksi sosial. Variabel bebas dalam penelitian ini adalah pola asuh orangtua. Kovariat dalam penelitian ini adalah penggunaan gadget. Definisi operasional dari masing-masing variabel penelitian adalah sebagai berikut:

Interaksi Sosial

Interaksi sosial adalah suatu hubungan antara individu dengan individu, individu dengan kelompok, dan kelompok dengan kelompok, dimana didalamnya terdapat sebuah kontak sosial dan komunikasi, sehingga terbentuk hubungan sosial yang saling memengaruhi antara individu yang satu dengan individu lainnya dalam lingkungan sosial.

Pola Asuh Orangtua

Pola asuh orangtua adalah cara orangtua dalam berinteraksi dengan anak, memberikan pendidikan baik secara langsung maupun tidak langsung, dengan tujuan untuk memperoleh suatu perilaku yang diinginkan.

Gadget

$\overline{\text { Gadget }}$ adalah berbagai macam perangkat elektronik, seperti laptop, smartphone, iPad, ataupun tablet, lengkap dengan berbagai fitur dan aplikasi yang tersedia, yang diciptakan 
khusus untuk mempermudah kehidupan manusia dalam mengakses segala informasi yang ada di dunia ini.

\section{Subjek Penelitian}

Sampel yang digunakan dalam penelitian ini adalah murid Taman Kanak-kanak (TK) Adhi Mekar Indonesia dan TK Bintang Besar yang terpilih melalui proses sampling. Populasi yang digunakan dalam penelitian ini memiliki kriteria yaitu anak prasekolah berusia 3 hingga 6 tahun, sedang menempuh pendidikan di taman kanak-kanak di Denpasar, dan menggunakan gadget.

\section{Lokasi Penelitian}

Penelitian ini dilakukan di 2 sekolah, yaitu TK Adhi Mekar Indonesia dan TK Bintang Besar. Penentuan nama-nama sekolah tersebut menggunakan teknik simple random sampling.

\section{Alat Ukur}

Penelitian ini menggunakan tiga buah alat ukur, yaitu skala interaksi sosial, skala pola asuh orangtua, dan angket penggunaan gadget. Skala interaksi sosial dan pola asuh orangtua disusun menggunakan skala Likert, yang terdiri dari empat kategori jawaban yaitu sangat tidak setuju, tidak setuju, setuju, dan sangat setuju. Masing-masing skala mengandung pernyataan favorable (mendukung objek sikap) dan pernyataan unfavorable (tidak mendukung objek sikap).
\end{abstract}

Skala interaksi sosial disusun berdasarkan aspek-aspek interaksi sosial menurut Gillin dan Gillin (dalam Soekanto, 2007) terdiri dari kerja sama, akomodasi, dan asimilasi. Skala interaksi sosial berjumlah 40 aitem yang terdiri dari 20 aitem favorable dan 20 aitem unfavorable. Skala pola asuh orangtua disusun berdasarkan aspek-aspek pola asuh orangtua menurut Baumrind (dalam Mussen, 1994) terdiri dari pola asuh otoriter, pola asuh permisif, dan pola asuh demokratis. Skala pola asuh orangtua berjumlah 38 aitem yang terdiri dari 19 aitem favorable dan 19 aitem unfavorable. Angket intensitas penggunaan gadget disusun berdasarkan teori Sigman (2010), yang diklasifikasikan menjadi tiga kategori, yaitu tinggi, sedang, dan rendah. Angket penggunaan gadget terdiri dari satu buah pertanyaan mengenai intensitas subjek menggunakan gadget dalam waktu satu hari.

Pada penelitian ini dilakukan serangkaian uji validitas dan reliabilitas. Terdapat dua jenis pengukuran validitas dalam penelitian ini, yaitu validitas isi dan validitas konstruk. Pengukuran terhadap validitas isi dalam penelitian ini dilakukan dengan teknik expert judgement yang dilakukan oleh dosen dari Program Studi Sarjana Psikologi Universitas Udayana. Pengukuran validitas konstruk dilakukan dengan melihat tampilan output Alpha Cronbach pada kolom corrected total-item correlation. Suatu aitem dikatakan valid apabila skor corrected total-item correlation lebih besar daripada 0,30 (Sugiyono, 2014). Uji reliabilitas dilakukan dengan melihat nilai Alpha Cronbach. Suatu alat ukur dapat dikatakan memiliki reliabilitas yang baik apabila memiliki nilai Alpha Cronbach diatas 0,60 (Sugiyono, 2014).
Uji coba alat ukur ini menggunakan subjek yang memiliki karakteristik serupa dengan subjek penelitian. Uji coba dilakukan sebanyak dua kali yang dilaksanakan pada tanggal 6 dan 14 Desember 2017 di TK Bakti 3 dengan menyebar sebanyak 45 skala kepada responden penelitian yaitu wali murid dan guru di sekolah tersebut. Dari total 45 skala yang dibagikan, jumlah skala yang memenuhi syarat untuk dianalisis adalah 30 skala, yang selanjutnya diolah menggunakan program SPSS 22.0 for Windows.

Hasil uji validitas skala interaksi sosial menunjukkan bahwa dari total 40 aitem, 27 aitem dinyatakan valid dan 13 aitem gugur. Nilai koefisien korelasi aitem total berkisar antara 0,315 sampai 0,893. Hasil uji validitas skala pola asuh orangtua menunjukkan bahwa dari total 38 aitem, 22 aitem dinyatakan valid dan 16 aitem gugur. Nilai koefisien korelasi aitem total berkisar antara 0,30 sampai 0,866. Hasil uji reliabilitas skala interaksi sosial menunjukkan koefisien sebesar 0,951, dan hasil uji reliabilitas skala pola asuh orangtua menunjukkan koefisien sebesar 0,907.

\section{Teknik Analisis Data}

Uji asumsi dalam penelitian ini adalah uji normalitas, uji homogenitas, dan uji linearitas. Setelah data penelitian memenuhi uji asumsi tersebut, dilakukan uji hipotesis penelitian menggunakan teknik analysis of covariance (ANCOVA) dengan bantuan program SPSS 22.0 for Windows.

\section{HASIL PENELITIAN}

\section{Karakteristik Subjek}

Subjek pada penelitian ini berjumlah 100 orang yang merupakan murid dari TK Adhi Mekar Indonesia dan TK Bintang Besar. Mayoritas subjek berasal dari TK Adhi Mekar Indonesia dengan persentase sebesar $88 \%$. Berdasarkan jenis kelamin, mayoritas subjek adalah laki-laki, dengan persentase sebesar 57\%. Berdasarkan usia, mayoritas subjek berusia 5 tahun, dengan persentase sebesar 53\%. Berdasarkan usia mengenal gadget, mayoritas subjek berusia 3 tahun, dengan persentase sebesar 36\%. Berdasarkan jenis gadget yang digunakan, mayoritas subjek menggunakan smartphone, dengan persentase sebesar 94\%. Berdasarkan jenis aplikasi yang digunakan, mayoritas subjek mengakses youtube, dengan persentase sebesar $81 \%$.

\section{Deskripsi Data Penelitian}

Interaksi Sosial

Berdasarkan hasil deskripsi pada tabel 1 (terlampir) menunjukkan bahwa variabel interaksi sosial memiliki mean teoretis sebesar 67,5 dan mean empiris sebesar 84,14 dengan perbedaan sebesar 16,64. Hal ini menandakan subjek penelitian memiliki taraf interaksi sosial yang tinggi karena nilai mean empiris lebih besar daripada mean teoretis $(84,14>$ 67,5). Berdasarkan penyebaran frekuensi, subjek dalam penelitian ini menghasilkan rentang skor antara 35 sampai dengan 108, serta 92\% subjek memiliki skor di atas mean teoretis. Kategorisasi skor interaksi sosial dapat dilihat pada tabel 2 (terlampir). Berdasarkan kategorisasi skor interaksi sosial di atas, dapat dilihat bahwa subjek yang memiliki taraf 
interaksi sosial yang tinggi sebanyak 50 orang atau persentase sebesar 50\%. Hal ini menunjukkan bahwa mayoritas subjek memiliki taraf interaksi sosial yang tinggi.

\section{Pola Asuh Orangtua}

Hasil deskripsi statistik skor pola asuh orangtua dapat dilihat pada tabel 3 (terlampir).

Pada penelitian ini, subjek terbagi ke dalam tiga kategori pola asuh, yakni pola asuh otoriter, pola asuh permisif, dan pola asuh demokratis. Kategorisasi skor pola asuh Orangtua dapat dilihat pada tabel 4 (terlampir).

Berdasarkan kategorisasi skor pola asuh orangtua di atas, dapat dilihat bahwa mayoritas subjek diasuh menggunakan pola asuh demokratis dengan persentase sebesar $53 \%$.

\section{Penggunaan Gadget}

Hasil deskripsi di atas pada tabel 5 (terlampir) menunjukkan bahwa variabel penggunaan gadget memiliki memiliki mean teoretis sebesar 75 dan mean empiris sebesar 61,50 dengan perbedaan sebesar 13,50. Hal ini menandakan subjek penelitian memiliki intensitas penggunaan gadget yang rendah karena nilai mean empiris lebih kecil daripada mean teoretis $(61,50<75)$. Berdasarkan penyebaran frekuensi, subjek dalam penelitian ini menghasilkan rentang skor antara 30 sampai dengan 120, serta 33\% subjek memiliki skor di atas mean teoretis. Kategorisasi skor penggunaan gadget dapat dilihat pada tabel 6 (terlampir). Berdasarkan kategorisasi skor penggunaan gadget di atas, dapat dilihat bahwa mayoritas subjek memiliki taraf penggunaan gadget yang sangat rendah dengan persentase sebesar $36 \%$.

\section{Uji Asumsi}

\section{Uji Normalitas}

Uji normalitas dilakukan dengan menggunakan uji Kolmogorov-Smirnov pada program SPSS 22.0 for Windows. Nilai residual dinyatakan berdistribusi normal jika $\mathrm{p}>0,05$. Berdasarkan hasil uji normalitas, nilai residual menunjukkan nilai Kolmogorov-Smirnov sebesar 0,077 dengan signifikansi sebesar $0,150(\mathrm{p}>0,05)$, sehingga data variabel interaksi sosial, pola asuh Orangtua, dan penggunaan gadget berdistribusi normal. Hasil uji normalitas dapat dilihat pada tabel 7 (terlampir).

Uji Homogenitas

Uji homogenitas dilakukan dengan menggunakan Levene Test pada program SPSS 22.0 for Windows. Berdasarkan hasil uji homogenitas, distribusi data bersifat homogen karena menunjukkan angka 1,367 dengan signifikansi sebesar 0,159 ( $p>0,05)$. Hasil uji homogenitas dapat dilihat pada tabel 8 (terlampir).

\section{Uji Linearitas}

Uji linearitas dilakukan dengan menggunakan uji compare mean pada program SPSS 22.0 for Windows. Data dapat dikatakan memiliki hubungan yang linear apabila nilai signifikansi $(p)$ pada linearity $<0,05$ dan nilai signifikansi pada deviation from linearity $>0,05$. Berdasarkan hasil uji linearitas, variabel interaksi sosial dan pola asuh Orangtua memiliki hubungan yang linear karena nilai signifikansi pada kolom linearity menunjukkan angka 0,000 ( $\mathrm{p}<0,05)$, dan nilai signifikansi pada kolom deviation from linearity menunjukkan angka 0,221 $(>0,05)$. Variabel interaksi sosial dan penggunaan gadget juga memiliki hubungan yang linear karena nilai signifikansi pada kolom linearity menunjukkan angka 0,000 ( $\mathrm{p}<0,05)$, dan nilai signifikansi pada kolom deviation from linearity menunjukkan angka 0,576 $(>0,05)$. Hasil uji linearitas data dapat dilihat pada tabel 9 (terlampir).

\section{Uji Hipotesis}

\section{Uji Hipotesis Mayor}

Pada tabel 10 (terlampir) terdapat nilai corrected model yang merupakan nilai pengaruh semua variabel independent secara simultan atau bersama-sama terhadap variabel dependent. Artinya, nilai corrected model pada tabel 10 adalah nilai dari variabel pola asuh Orangtua dan penggunaan gadget secara bersama-sama berpengaruh terhadap interaksi sosial. Nilai signifikansi pada corrected model adalah sebesar 0,000 (p < 0,05), sehingga kesimpulan yang diperoleh adalah pola asuh Orangtua dan penggunaan gadget memberikan kontribusi terhadap tingkat interaksi sosial anak prasekolah.

Perbedaan antara dilakukan dan tidak dilakukannya kontrol pada penggunaan gadget dapat dilihat dari tabel 11 (terlampir). Pada tabel tersebut menunjukkan nilai adjusted $R$ squared interaksi sosial jika ditinjau dari pola asuh Orangtua saja memiliki nilai sebesar 0,276. Nilai tersebut berarti bahwa variabel interaksi sosial dapat dijelaskan oleh variabel pola asuh Orangtua sebesar 27,6\%, setelah dilakukan kontrol pada penggunaan gadget terjadi kenaikan nilai adjusted $R$ squared menjadi 0,584. Nilai tersebut berarti bahwa variabel interaksi sosial dapat dijelaskan oleh variabel pola asuh Orangtua dan penggunaan gadget sebesar 58,4\%. Adanya kenaikan sebesar $30,8 \%$ setelah dilakukan kontrol terhadap penggunaan gadget menandakan bahwa model menjadi lebih baik yang berarti tingkat kesalahan dalam uji ini dapat diminimalisir.

Uji Hipotesis Minor

Pada variabel pola asuh orangtua terdapat nilai signifikansi sebesar $\mathrm{p}=0,022(\mathrm{p}<0,05)$. Hal tersebut menunjukkan bahwa pola asuh orangtua berperan terhadap interaksi sosial anak prasekolah. Pada variabel penggunaan gadget terdapat nilai signifikansi sebesar $\mathrm{p}=0,000(\mathrm{p}<0,05)$, hal tersebut menunjukkan bahwa penggunaan gadget berperan terhadap interaksi sosial anak prasekolah. Hasil uji hipotesis minor dapat dilihat pada tabel 12 (terlampir).

\section{PEMBAHASAN DAN KESIMPULAN}

Berdasarkan hasil penelitian yang telah didapatkan dan dianalisis dengan menggunakan uji ANCOVA, dapat diketahui bahwa hipotesis mayor penelitian yaitu pola asuh orangtua dan penggunaan gadget berperan terhadap interaksi sosial anak prasekolah. Hal ini dapat dilihat dari nilai signifikansi pada corrected model yang menunjukkan angka 0,000 dan nilai $\mathrm{F}$ sebesar 35,802 . Hal ini menunjukkan bahwa pada tingkat kepercayaan $95 \%$ pola asuh orangtua dan penggunaan gadget memiliki kontribusi terhadap interaksi sosial anak prasekolah. Nilai adjusted $R$ squared sebesar 0,584 memiliki arti bahwa variabel interaksi sosial dapat dijelaskan oleh variabel pola asuh orangtua dan penggunaan gadget adalah sebesar 58,4\%. Sebesar $41,6 \%$ lainnya variabel 
interaksi sosial dipengaruhi oleh variabel lain yang tidak diteliti dalam penelitian ini. Interaksi sosial dapat dijelaskan sebesar $27,6 \%$ oleh variabel pola asuh orangtua. Kontribusi tersebut dapat dilihat pada nilai adjusted $R$ squared sebesar 0,276 sebelum dilakukan kontrol terhadap variabel penggunaan gadget. Nilai interaksi sosial meningkat menjadi 0,584 setelah adanya kontrol pada penggunaan gadget, menunjukkan bahwa penggunaan gadget lebih berperan dibanding pola asuh orangtua terhadap interaksi sosial. Adanya kenaikan nilai adjusted $R$ squared sebesar 30,8\% menandakan bahwa model regresi menjadi lebih baik. Kontribusi penggunaan gadget dapat dilihat dari hasil F hitung sebesar 72,173 dan nilai signifikansi sebesar 0,000 menunjukkan bahwa penggunaan gadget secara signifikan berinteraksi dengan interaksi sosial. Kontribusi faktor lain yang memengaruhi interaksi sosial adalah sebesar $41,6 \%$. Faktor lain yang memengaruhi interaksi sosial tidak diteliti dalam penelitian ini.

Hal ini sejalan dengan pandangan sejumlah teoretisi dan peneliti yang mengatakan bahwa hubungan Orangtua dengan anak berfungsi sebagai landasan emosional yang digunakan anak untuk mengeksplorasi dan menikmati hubungan dengan teman sebaya. Hubungan orangtua dengan anak memengaruhi hubungan anak dengan teman sebaya. Anak-anak belajar tentang bagaimana berhubungan dengan figur pemegang otoritas dari orangtuanya. Melalui teman sebaya, anak-anak juga belajar mengenai cara berinteraksi dan melakukan hubungan timbal balik dengan teman seusianya (Santrock, 2007). Berdasarkan hasil penelitian yang dilakukan oleh (Novitasari \& Khotimah, 2016) menunjukkan bahwa penggunaan gadget memberikan dampak terhadap interaksi sosial anak. Hasil penelitian lainnya menunjukkan bahwa penggunaan smartphone berpengaruh signifikan terhadap pola interaksi sosial anak balita sebesar 40,2 \%. Penggunaan smartphone selain untuk bermain, bisa bermanfaat untuk belajar (Marsal \& Hidayati, 2017).

\section{Hipotesis Minor I: Pola Asuh Orangtua Berperan terhadap Interaksi Sosial Anak Prasekolah}

Berdasarkan hasil penelitian yang telah dilakukan, dapat diketahui bahwa hipotesis minor penelitian yaitu pola asuh orangtua memiliki peran yang signifikan terhadap interaksi sosial anak prasekolah dapat diterima. Hal ini dapat dilihat dari hasil analisis menggunakan uji ANCOVA dengan nilai signifikansi yang menunjukkan angka 0,022 ( $p<0,05)$. Hasil tersebut menunjukkan bahwa pola asuh orangtua berperan terhadap interaksi sosial anak prasekolah. Hal ini sejalan dengan hasil penelitian yang dilakukan oleh Suharsono (2009) menunjukkan bahwa terdapat hubungan yang signifikan antara pola asuh orangtua dengan kemampuan sosialisasi anak usia prasekolah. Hal serupa juga diungkapkan oleh Setiani (2017) menunjukkan bahwa ada hubungan yang signifikan antara pola asuh orangtua dengan perkembangan personal sosial anak.

Pola asuh dapat didefinisikan sebagai suatu gaya mendidik yang dilakukan oleh orangtua untuk membimbing dan mendidik anak-anaknya dalam proses interaksi yang bertujuan untuk memperoleh suatu perilaku yang diinginkan (Gunarsa,
1990). Maccoby menyatakan bahwa pola asuh orangtua adalah gambaran interaksi orangtua dengan anak, dimana orangtua mengekspresikan sikap-sikap atau perilaku, nilai, minat dan harapanya dalam mengasuh dan memenuhi kebutuhan anak (dalam Yanti, 2005). Pola asuh juga dapat diartikan sebagai suatu kedisiplinan dalam mengajarkan anak tentang perilaku moral yang dapat diterima kelompok, dengan tujuan untuk memberitahukan anak sesuatu yang baik dan buruk serta mendorongnya untuk berperilaku dengan standar yang berlaku dalam masyarakat di lingkungan sekitarnya (Hurlock, 1993).

Pada penelitian ini, 53\% responden menerapkan pola asuh demokratis, $27 \%$ responden menerapkan pola asuh otoriter, dan $20 \%$ menerapkan pola asuh permisif. Hal ini sesuai dengan pendapat Soetjiningsih (2013), bahwa orangtua yang menerapkan pola asuh demokratis akan memengaruhi kemampuan sosialisasi anak, karena anak hidup dalam keluarga yang selalu mendukung dalam cinta kasih, kehangatan dan interaksi keluarga yang harmonis, sehingga anak mempunyai penyesuaian sosial yang baik dan bisa tumbuh dan berkembang secara optimal. Penelitian sebelumnya yang mendukung adalah Pratiwi (2013) tentang pola asuh orangtua dengan perkembangan mental anak pada proses tumbuh kembang, yang menyatakan bahwa pola asuh yang paling banyak diterapkan orangtua adalah pola asuh demokratis, yang dapat memengaruhi perkembangan mental anak menjadi baik yaitu sebesar $70,37 \%$. Hal ini selaras dengan penelitian yang dilakukan Suharsono (2009) keluarga dengan pola asuh demokratis dapat dijumpai pada keluarga seimbang yang ditandai oleh keharmonisan hubungan (relasi) antara ayah dan ibu, ayah dengan anak, serta ibu dengan anak. Hal ini tentu saja akan mempunyai pengaruh yang lebih baik dalam perkembangan jiwa anak.

\section{Hipotesis Minor II: Penggunaan Gadget Berperan terhadap Interaksi Sosial Anak Prasekolah}

Berdasarkan hasil penelitian yang telah dilakukan, dapat diketahui bahwa hipotesis minor penelitian yaitu penggunaan gadget memiliki peran yang signifikan terhadap interaksi sosial anak prasekolah dapat diterima. Hal ini dapat dilihat dari hasil analisis menggunakan uji ANCOVA dengan nilai signifikansi yang menunjukkan angka $0,000(p<0,05)$. Hasil tersebut menunjukkan bahwa penggunaan gadget berperan terhadap interaksi sosial anak prasekolah. Hasil penelitian ini sejalan dengan penelitian oleh Novitasari \& Khotimah (2016) yang menunjukkan bahwa penggunaan gadget berdampak pada interaksi sosial anak usia 5-6 tahun. Penelitian serupa juga dilakukan oleh Gunawan (2017) menunjukkan bahwa terdapat hubungan antara durasi penggunaan gadget dengan tingkat perkembangan sosial anak prasekolah.

Pada penelitian ini, 36\% subjek menggunakan gadget dengan intensitas sangat rendah (30 menit per hari), 31\% subjek menggunakan gadget dengan intensitas rendah (60 menit per hari), dan $25 \%$ subjek menggunakan gadget dengan intensitas tinggi (90 menit per hari), dan $8 \%$ subjek menggunakan gadget dengan intensitas yang sangat tinggi (120 menit per hari). Hal ini sejalan dengan penelitian yang dilakukan oleh Efendi, Astuti, \& Rahayu (2017) menunjukkan bahwa 
semakin tinggi penggunaan media baru maka interaksi sosial anak akan cenderung semakin rendah.

Kertergantungan terhadap gadget pada anak disebabkan oleh lamanya durasi dalam menggunakan gadget. Bermain gadget dengan durasi yang cukup panjang dan dilakukan setiap hari, dapat membuat anak berkembang ke arah pribadi yang asosial. Dampak yang ditimbulkan dari hal itu sebenarnya adalah dapat membuat anak lebih bersikap individualis karena lama kelamaan menyebabkan lupa berkomunikasi dan berinteraksi terhadap lingkungan di sekitarnya (Simamora, 2016). Hal tersebut dapat menyebabkan interaksi sosial antara anak dengan masyarakat, lingkungan sekitar berkurang, bahkan semakin luntur (Ismanto \& Onibala, 2015).

\section{DAFTAR PUSTAKA}

Azwar, S. (2009). Sikap manusia teori dan pengukurannya. Yogyakarta: Pustaka Pelajar.

Azwar, S. (2014). Reliabilitas dan validitas. Edisi Keempat. Yogyakarta: Pustaka Pelajar.

Creswell, J. W. (2009). Research design pendekatan kualitatif, kuantitatif, dan mixed. Edisi Ketiga. Yogyakarta: Pustaka Pelajar.

Delima, R., Arianti, N., \& Pramudyawardani, B. (2015). Identifikasi kebutuhan pengguna untuk aplikasi permainan edukasi bagi anak usia 4 sampai 6 tahun. Jurnal Teknologi Informasi dan Sistem Informasi, 1(1).

Efendi, A., Astuti, P. I., \& Rahayu, N. T. (2017). Analisis pengaruh penggunaan media baru terhadap pola interaksi sosial anak di Kabupaten Sukoharjo. Jurnal Penelitian Humaniora, 18 (2), 12-24

Euis, S. (2004). Mengasuh anak dengan hati. Jakarta: PT Elex Media Komputindo.

Fajrina, H. N. (2015, November 4). Tingkat kecanduan gadget di usia dini semakin mengkhawatirkan. CNN Indonesia.

Gea, A. A., Wulandari, A. P., \& Babari, Y. (2003). Character building ii, relasi dengan sesama. Jakarta: PT Gramedia.

Gerungan. (2003). Psikologi sosial. Bandung: PT Eresco

Ghozali, I. (2005). Aplikasi analisis multivariate dengan program SPSS. Semarang: Badan Penerbit Universitas Diponegoro.

Gunarsa, S. (2002). Dari anak sampai usia lanjut. Jakarta: PT BPK Gunung Mulia

Gunarsa, Y. S. (2003). Psikologi perkembangan anak dan remaja. Jakarta: PT BPK Gunung Mulia.

Gunawan, M. A. (2017). Hubungan durasi penggunaan gadget terhadap perkembangan sosial anak prasekolah di TK PGRI 33 Sumurboto Banyumanik. Skripsi. Departemen Ilmu Keperawatan Fakultas Kedokteran Universitas Diponegoro.

Harfiyanto, D., Utomo, C. B., \& Budi, T. (2015). Pola interaksi sosial siswa pengguna gadget di SMA N 1 Semarang. Journal of Educational Social Studies, 01-05.

Hurlock, B. (1993). Psikologi perkembangan edisi ke-5. Jakarta: Erlangga.

Indrawan, P. (2014). Pengaruh gadget terhadap tumbuh kembang psikososial anak PAUD. Retrieved April 12, 2017, from http://library.binus.ac.id

Irawan, J., \& Armayati, L. (2013). Pengaruh penggunaan gadget terhadap kemampuan bersosialisasi pada remaja. An-Nafs, $8(2), 29-38$.

Ismanto, Y., \& Onibala, F. (2015). Hubungan penggunaan gadget dengan tingkat prestasi siswa di SMA Negeri 9 Manado. Ejournal Keperawatan, 3(2).
Iswidharmanjaya, D. (2014). Bila si kecil bermain gadget. Beranda Agency.

Iswidharmanjaya, D., \& Agency, B. (2014). Panduan bagi orangtua untuk memahami faktor-faktor anak kecanduan gadget. Bisakimia.

Izzaty, R. E. (2017). Perilaku anak prasekolah, masalah dan cara menghadapinya. Jakarta: PT Elex Media Komputindo.

Kartono, K. (1979). Psikologi anak. Bandung: Penerbit Alumni.

Khotimah, N. (2016). Dampak penggunaan gadget terhadap interaksi sosial anak usia 5-6 tahun. Jurnal Pendidikan Anak Usia Dini Indonesia, 2(2), 26-29.

Mahmudah, S. (2010). Psikologi sosial. Malang: UIN Maliki Press.

Manumpil, B., \& Ismanto, Y. (2015). Hubungan penggunaan gadget dengan tingkat prestasi siswa di SMA Negeri 9 Manado. Ejournal Keperawatan.

Marsal, A., \& Hidayati, F. (2017). Pengaruh smartphone terhadap pola interaksi sosial pada anak balita di lingkungan keluarga pegawai UIN Sultan Syarif Kasim Riau. Jurnal Ilmiah Rekayasa dan Manajemen Sistem Informasi, 3(1), 78-84.

Maulida, \& Hidayahti. (2013). Menelisik pengaruh penggunaan aplikasi gadget terhadap perkembangan psikologis anak usia dini. Jurnal Ilmiah Teknologi Pendidikan.

Mussen, P. (1994). Perkembangan dan kepribadian anak. Jakarta: Archan.

Mutiah, D. (2012). Psikologi Bermain Anak Usia Dini. Jakarta: Kencana Prenada Media.

Novitasari, W., \& Khotimah, N. (2016). Dampak penggunaan gadget terhadap interaksi sosial anak usia 5-6 tahun. Jurnal PAUD Teratai, 5(3), 182-186.

Pratiwi, A. (2013). Hubungan antara pola asuh orangtua dengan perkembangan mental anak pada proses tumbuh kembang di SD Bentakan 1 Sukoharjo. Jurnal Ilmu Keperawatan, $1(2), 24-27$.

Pratiwi, P. (2015). Bila anak terlalu sering diasuh gadget.

Rideout, V. (2013). Zero to eight: electronic media in the lives of infants, toodlers and preschoolers. Common Sense Media Research Study.

Rowan, C. (2013, Agustus 25). The impact of technology on the developing child. The Huffington Post. Diakses dari http://www.huffingtonpost.com/crisrowan/technologychildren-

Sanjiwani, N. L., \& dkk. (2014). Pola asuh permisif ibu dan perilaku merokok pada remaja laki-laki di SMA Negeri 1 Semarapura. Jurnal Psikologi Udayana, Vol. 1, No. 2.

Santosa, S. (2004). Dinamika Kelompok. Jakarta: Bumi Aksara.

Santrock, J. (2007). Perkembangan Anak 2. (M. Rahmawati, Trans.) Jakarta: Erlangga.

Sari, T., \& Mitsalia, A. (2016). Pengaruh Penggunaan Gadget. Pengaruh Penggunaan Gadget terhadap Personal Sosial Anak USia Pra Sekolah di TKIT Al Mukmin, Vol. 13, No. 2.

Setiani, W. A. (2017). HUbungan Pola Asuh Orangtua dengan Perkembangan Personal Sosial Anak. Skripsi. Program Studi Ilmu Keperawatan Sekolah Tinggi Ilmu Kesehatan Jenderal Achmad Yani.

Sigman, A. (2010). The impact of screen media on children. $a$ eurovision for parliament, 89-109.

Simamora, A. S. (2016). Persepsi Orangtua Terhadap Dampak Penggunaan Gadget pada Anak Usia Pendidikan Dasar di Perumahan Bukit Kemiling Permai Kecamatan Kemiling Bandar Lampung. Universitas Lampung.

Soekanto, S. (1982). Sosiologi Suatu Pengantar. Jakarta: CV. Rajawali.

Soekanto, S. (1992). Sosiologi Suatu Pengantar. Jakarta: Rajawali. 
Soetjinigsih, C. H. (2012). Perkembangan Anak Sejak Pertumbuhan Sampai dengan Kanak-Kanak Akhir. Jakarta: Prenada Media Group.

etjiningsih. (2013). Tumbuh Kembang Anak. Jakarta: EGC.

Starburger, V. (2011). Children, adolescents, obesity and the media. Pediatrics.

Statistik, B. P. (2017). Banyaknya Sekolah, Murid, dan Guru Taman Kanak-Kanak/Raudhatul Anfal menurut Kabupaten/Kota Tahun 2013/2014. (Badan Pusat Statistik Provinsi Bali) Retrieved from https://www.bali.bps.go.id/linkTabelStatis/view/id/211

Sudijono, A. (2012). Pengantar Statistik Pendidikan. Jakarta: PT Raja Grafindo Persada.

Sugiyono. (2014). Metode Penelitian Kombinasi (Mixed Method). Bandung: Alfabeta.

Suharsono, T. J. (2009). Hubungan Pola Asuh Orangtua terhadap Kemampuan Sosialisasi pada Anak Prasekolah di TK Pertiwi Purwokerto Utara. Jurnal Keperawatan Soedirman, 4 (3), 112-116.

Susanto, A. (2012). Perkembangan Anak Usia Dini : Pengantar dalam Berbagai Aspeknya. Jakarta: Kencana Prenada Media Group.

Suyadi. (2010). Psikologi Belajar Anak Usia Dini. Yogyakarta: Pedadogia.

Syahra, R. (2003). Modal Sosial: Konsep dan Aplikasi. Jurnal Masyarakat dan Budaya.

Upton, P. (2012). Psikologi Perkembangan. (N. F. Widuri, Trans.) Jakarta: Erlangga.

Utami, W., \& dkk. (2017). Hubungan Tipe Pola Asuh Orangtua dengan Perkembangan Psikososial Anak Usia Prasekolah di TK Pertiwi 1 Desa Purbowangi, Kecamatan Buayan, Kabupaten Kebumen. Jurnal Ilmiah Kesehatan Keperawatan, Vol. 13, No. 1.

Walgito, B. (2003). Psikologi Sosial. Yogyakarta: Andi Yogyakarta. Wulandari, P. Y. (2016, Maret 17). Anak Asuhan Gadget. Liputan 6.

Yanti. (2005). Pola Asuh Orangtua terhadap Perilaku Sosial Anak. Skripsi. Universitas Gunadarma. 


\section{LAMPIRAN}

Tabel 1

Deskripsi Statistik Skor Interaksi Sosial

\begin{tabular}{ccccccccc}
\hline Var & $\mathrm{N}$ & $\begin{array}{c}\text { Mean } \\
\text { Teoretis }\end{array}$ & $\begin{array}{c}\text { Mean } \\
\text { Empiris }\end{array}$ & $\begin{array}{c}\text { Std. } \\
\text { Deviasi } \\
\text { Teoretis }\end{array}$ & $\begin{array}{c}\text { Std. } \\
\text { Deviasi } \\
\text { Empiris }\end{array}$ & $\begin{array}{c}\text { Sebaran } \\
\text { Teoretis }\end{array}$ & $\begin{array}{c}\text { Sebaran } \\
\text { Empiris }\end{array}$ & Nilai t \\
\hline IS & 100 & 67,5 & 84,14 & 13,5 & 12,448 & $27-108$ & $35-108$ & $\begin{array}{c}13,368 \\
(\mathrm{p}=0,000)\end{array}$ \\
\hline
\end{tabular}

Tabel 2

Kategorisasi Skor Interaksi Sosial

\begin{tabular}{cccc}
\hline Rentang Nilai & Kategori & Jumlah & Persentase \\
\hline $\mathrm{X} \leq 47,3$ & Sangat Rendah & 1 & $1 \%$ \\
$47,3<\mathrm{X} \leq 60,8$ & Rendah & 1 & $1 \%$ \\
$60,8<\mathrm{X} \leq 74,3$ & Sedang & 14 & $14 \%$ \\
$74,3<\mathrm{X} \leq 87,8$ & Tinggi & 50 & $50 \%$ \\
$87,8<\mathrm{X}$ & Sangat Tinggi & 34 & $34 \%$ \\
\hline
\end{tabular}

Tabel 3

Deskripsi Statistik Skor Pola Asuh Orangtua

\begin{tabular}{cccccccc}
\hline Var & N & $\begin{array}{c}\text { Mean } \\
\text { Teoretis }\end{array}$ & $\begin{array}{c}\text { Mean } \\
\text { Empiris }\end{array}$ & $\begin{array}{c}\text { Std. } \\
\text { Deviasi } \\
\text { Teoretis }\end{array}$ & $\begin{array}{c}\text { Std. } \\
\text { Deviasi } \\
\text { Empiris }\end{array}$ & $\begin{array}{c}\text { Sebaran } \\
\text { Teoretis }\end{array}$ & $\begin{array}{c}\text { Sebaran } \\
\text { Empiris }\end{array}$ \\
\hline Otoriter & 100 & 10 & 12,35 & 2 & 2,129 & $4-16$ & $7-16$ \\
Permisif & 100 & 15 & 14,39 & 3 & 3,648 & $6-24$ & $9-24$ \\
Demokratis & 100 & 30 & 30,50 & 6 & 6,939 & $12-48$ & $20-42$ \\
\hline
\end{tabular}

Tabel 4

Kategorisasi Skor Pola Asuh Orangtua

\begin{tabular}{ccc}
\hline Kategori & Jumlah & Persentase \\
\hline Pola Asuh Otoriter & 27 & $27 \%$ \\
Pola Asuh Permisif & 20 & $20 \%$ \\
Pola Asuh Demokratis & 53 & $53 \%$ \\
\hline
\end{tabular}

Tabel 5

Deskripsi Statistik Skor Penggunaan Gadget

\begin{tabular}{ccccccccc}
\hline Var & $\mathrm{N}$ & $\begin{array}{c}\text { Mean } \\
\text { Teoretis }\end{array}$ & $\begin{array}{c}\text { Mean } \\
\text { Empiris }\end{array}$ & $\begin{array}{c}\text { Std. } \\
\text { Deviasi } \\
\text { Teoretis }\end{array}$ & $\begin{array}{c}\text { Std. } \\
\text { Deviasi } \\
\text { Empiris }\end{array}$ & $\begin{array}{c}\text { Sebaran } \\
\text { Teoretis }\end{array}$ & $\begin{array}{c}\text { Sebaran } \\
\text { Empiris }\end{array}$ & Nilai t \\
\hline PG & 100 & 75 & 61,50 & 15 & 29,038 & $30-120$ & $30-120$ & $\begin{array}{c}-4,649 \\
(\mathrm{p}=0,000)\end{array}$ \\
\hline
\end{tabular}


Tabel 6

Kategorisasi Skor Penggunaan Gadget

\begin{tabular}{cccc} 
Rentang Nilai & Kategori & Jumlah & Persentase \\
\hline $\mathrm{X} \leq 52,5$ & Sangat Rendah & 36 & $36 \%$ \\
$52,5<\mathrm{X} \leq 67,5$ & Rendah & 31 & $31 \%$ \\
$67,5<\mathrm{X} \leq 82,5$ & Sedang & - & - \\
$82,5<\mathrm{X} \leq 97,5$ & Tinggi & 25 & $25 \%$ \\
$97,5<\mathrm{X}$ & Sangat Tinggi & 8 & $8 \%$ \\
\hline
\end{tabular}

Tabel 7

Hasil Uji Normalitas Variabel Penelitian

\begin{tabular}{ccc}
\hline Variabel & Kolmogorov-Sminnov & Asymp. Sig (2-tailed) \\
\hline Nilai Residual & 0,077 & 0,150 \\
\hline
\end{tabular}

Tabel 8

Hasil Uji Homogenitas Variabel Penelitian

\begin{tabular}{lcc}
\hline $\begin{array}{c}\text { Levene Test for Equality } \\
\text { of Variance }\end{array}$ & Levene Statistic & Sig. \\
\hline Distribusi Data & 1,367 & 0,159 \\
\hline
\end{tabular}

Tabel 9

Hasil Uji Linearitas Variabel Penelitian

\begin{tabular}{lclcc} 
& & & F & Sig. \\
\hline Interaksi Sosial*Pola & Between & Linearity & 30,060 & 0,000 \\
Asuh Orangtua & Group & $\begin{array}{l}\text { Deviation from } \\
\text { Linearity }\end{array}$ & 1,272 & 0,221 \\
Interaksi & Between & Linearity & 123,021 & 0,000 \\
Sosial*Penggunaan & Group & $\begin{array}{l}\text { Deviation from } \\
\text { Gadget }\end{array}$ & Linearity & \\
\hline
\end{tabular}


Tabel 10

Hasil Uji Hipotesis Mayor dengan Kontrol Kovariat

Dependent Variable: Interaksi Sosial

\begin{tabular}{lccccc}
\hline \multicolumn{1}{c}{ Source } & $\begin{array}{c}\text { Type III Sum of } \\
\text { Squares }\end{array}$ & Df & Mean Square & F & Sig. \\
\hline $\begin{array}{l}\text { Corrected } \\
\text { Model }\end{array}$ & $9222,265^{\mathrm{a}}$ & 4 & 2305,566 & 35,802 & 0,000 \\
\hline Intercept & 93906,505 & 1 & 93906,505 & 1458,229 & 0,000 \\
\hline $\begin{array}{l}\text { Penggunaan } \\
\text { Gadget }\end{array}$ & 4647,794 & 1 & 4647,794 & 72,173 & 0,000 \\
\hline $\begin{array}{l}\text { Pola Asuh } \\
\text { Orangtua }\end{array}$ & 649,447 & 3 & 216,482 & 3,362 & 0,022 \\
\hline Error & 6117,775 & 95 & 64,398 & & \\
\hline Total & 723294,000 & 100 & & & \\
\hline $\begin{array}{l}\text { Corrected } \\
\text { Total }\end{array}$ & 15340,040 & 99 & & & \\
\hline
\end{tabular}

a. $R$ Squared $=0,601$ (Adjusted $R$ Squared $=0,584)$

Tabel 11

Hasil Uji Hipotesis Mayor Tanpa Kontrol Kovariat

Dependent Variable: Interaksi Sosial

\begin{tabular}{lccccc}
\hline \multicolumn{1}{c}{ Source } & $\begin{array}{c}\text { Type III Sum of } \\
\text { Squares }\end{array}$ & Df & Mean Square & F & Sig. \\
\hline $\begin{array}{l}\text { Corrected } \\
\text { Model }\end{array}$ & $4574,471^{\mathrm{a}}$ & 3 & 1524,824 & 13,597 & 0,000 \\
\hline Intercept & 240235,386 & 1 & 240235,386 & 2142,255 & 0,000 \\
\hline $\begin{array}{l}\text { Pola Asuh } \\
\text { Orangtua }\end{array}$ & 4574,471 & 3 & 1524,824 & 13,597 & 0,000 \\
\hline Error & 10765,569 & 96 & 112,141 & & \\
\hline Total & 723294,000 & 100 & & & \\
\hline $\begin{array}{l}\text { Corrected } \\
\text { Total }\end{array}$ & 15340,040 & 99 & & & \\
\hline
\end{tabular}

a. $\quad$ S Squared $=0,298$ (Adjusted $R$ Squared $=0,276$ ) 
Tabel 12

Hasil Uji Hipotesis Minor

Dependent Variable: Interaksi Sosial

\begin{tabular}{lccccc}
\hline \multicolumn{1}{c}{ Source } & $\begin{array}{c}\text { Type III Sum of } \\
\text { Squares }\end{array}$ & Df & Mean Square & F & Sig. \\
\hline $\begin{array}{l}\text { Corrected } \\
\text { Model }\end{array}$ & $9222,265^{\mathrm{a}}$ & 4 & 2305,566 & 35,802 & 0,000 \\
\hline Intercept & 93906,505 & 1 & 93906,505 & 1458,229 & 0,000 \\
\hline $\begin{array}{l}\text { Penggunaan } \\
\text { Gadget }\end{array}$ & 4647,794 & 1 & 4647,794 & 72,173 & 0,000 \\
\hline $\begin{array}{l}\text { Pola Asuh } \\
\text { Orangtua }\end{array}$ & 649,447 & 3 & 216,482 & 3,362 & 0,022 \\
\hline Error & 6117,775 & 95 & 64,398 & & \\
\hline Total & 723294,000 & 100 & & & \\
\hline $\begin{array}{l}\text { Corrected } \\
\text { Total }\end{array}$ & 15340,040 & 99 & & & \\
\hline
\end{tabular}

a. $R$ Squared $=0,601$ (Adjusted $R$ Squared $=0,584$ ) 